Bull. Fac. Agric., Cairo Univ., 61: 238-249 (2010).

\title{
EFFECT OF MINIMUM INPUTS OF INTEGRATED WEED CONTROL PROGRAMS IN WHEAT PRODUCTION UNDER NEWLY RECLAIMED SOIL CONDITIONS
}

(Received: 5.5.2010)

\author{
By \\ M. H. EL-Deek., M. S. Abdel-Raouf., M. M. Abdel Aleem " and M. I. T. El-Bagoury * \\ Agronomy Department, Faculty of Agriculture, Cairo University, "Field Croups Research Institute, \\ Agricultural Research Center, Giza, Egypt.
}

\begin{abstract}
Two field experiments were conducted at Salah Al-Abd village, El-Bostan region, El-Behera Governorate, Egypt during 2005/2006 and 2006/2007 seasons, to study the effect of weed control treatments (Harmony Extra herbicide (Thifensulfuron), applied at the rates of 24 and $18 \mathrm{~g} / \mathrm{fed}$., hand weeding (twice) and unweeding (check), seeding systems (drilling and broadcasting, with recommended rate and $150 \%$ of the recommended seeding rates for each method) and two nitrogen fertilizer levels (100 and $75 \mathrm{~kg} \mathrm{~N} / \mathrm{fed}$.) on the productivity of wheat under the conditions of new lands.

Results indicate that using Harmony Extra herbicide at both rates was significant in reducing fresh weight of broadleaved weeds as well the significant increase in both of the number of kernels /spike, the number of spikes $/ \mathrm{m}^{2}$ and thus increase grain yield, from the back of resistance recommended to use the lower rate of this herbicide.

There was significant effect for seeding system on fresh weight of broad leaved weeds, where it was noted that increasing seeding rate of wheat crop reduced fresh weight of broad leaved weeds as well as had a reduction in the number of kernels /spike, but it had an increase in number of spikes $/ \mathrm{m}^{2}$ thus, grain yield did not significantly affected.

Decreasing nitrogen fertilizer levels caused significant reduction in fresh weight of broad leaved weeds, leading to a reduction in the number of spikes $/ \mathrm{m}^{2}$, which was reflected on the reduction in grain yield.
\end{abstract}

Key words: nitrogen fertilizer, seeding systems, weed control, wheat, yield.

\section{INTRODUCTION}

Wheat is one of the most important crops in the world. It is considered the main source of food in Egypt. So, increasing wheat production must be a national interest to minimize the gab between production and consumption.

Weeds are the most important problem in wheat causing loss of yield. The reduction of wheat yield due to weed infestation amounted 30\% (Nisha et al., 1999), 31.9\% (Tiwari and Parihar, 1997) or $61 \%$ (Hucl, 1998) as compared to weed free control.

Seeding system and nitrogen fertilizer application are two main factors affecting directly the growth and productivity of wheat plant.

Application of harmony herbicide caused significant reduction of fresh and dry weights of broadleaved weeds $/ \mathrm{m}^{2}$ (El-Metwally and ElRokiek, 2007). The application of Thifensulfuronmethyl significantly increased the number of kernels/spike, and the number of spike $/ \mathrm{m}^{2}$ (Khan et al., 2004 and El-Metwally and El-Rokiek, 2007). Harmony application and/or hand weeding gave significant increase in grain yield, compared to unweeded check (Adamczewski et al., 2005 and El-Metwally and El-Rokiek, 2007).

Drilling wheat was a successful method in reducing fresh and dry weights of broad-leaved weeds comparing to broadcasting (El-Naggar, 1996 and Pandey and Kumar, 2005). Also, dry weight of broadleaved weed decreased as seeding rate was increased up to $120 \mathrm{~kg} / \mathrm{ha}$. (Galal, 2003). Drilling system for wheat gave positive increase in the number of wheat kernels/spike (Khan et al., 2007). Increasing wheat seeding rate from 34 to $195 \mathrm{~kg}$ seeds/ha or from 120 to 770 seeds $/ \mathrm{m}^{2}$ significantly tended to decrease wheat number of kernels/spike (Schillinger, 2005), while GuillenPortal et al. (2006) had no significant effect for wheat seeding rate on the number of kernels/spike. Galal, (2003) found a positive increase in wheat number of spike $/ \mathrm{m}^{2}$ and grain yield compared with 
broadcasting method. Lithourgidis, et al. (2006) reported that plant density also affected the number of spikes $/ \mathrm{m}^{2}$, while, grain yield was not affected by the used seeding rate.

In wheat fields, fresh weight of weed plants $/ \mathrm{m}^{2}$ significantly was reduced by increasing nitrogen fertilizer level (Naik et al., 1997). But Azad and Singh (1997) and Singh (1997) obtained a significant increase in dry matter of weed plants with increasing nitrogen fertilizer levels. Simon et al. 2002 reported that increasing nitrogen fertilizer level significantly affected the number of kernels/spike and the number of spikes $/ \mathrm{m}^{2}$. Some investigators obtained high productivity of grain yield of wheat by increasing nitrogen fertilizer application (Mehasen, 1999 and Mowafy, 2002).

The sandy soil is poor in nitrogen and organic matter, therefore, it could be compensated by adding nitrogen fertilizer and minimize weed competition raising nitrogen use efficiency for wheat. Therefore, the main objective of this investigation was to study the effect of low inputs and weed control on the productivity of wheat under the conditions of new lands.

\section{MATERIALS AND METHODS}

Two field experiments were conducted at Salah Al-Abd village, El-Bostan region, El-Behera Governorate, Egypt to study the effect of low inputs and weed control on the productivity of wheat under the conditions of new lands during the two winter seasons of 2005/2006 and 2006/2007.

The experimental design was spilt-spilt-plot in Randomized Complete Block (RCB) with four replications. Wheat 'Gemmiza 9 grains were planted in rows using seed driller, or broadcasted on plot area of 8.4 square meters (12 rows, $3.5 \mathrm{~m}$ long and $20 \mathrm{~cm}$ apart).

The experiments were planted in the last week of November and harvested in the first week of May, in the respective two seasons.

\subsection{Experimental treatments}

\subsubsection{Weed control}

Four weed control treatments were used in this study as follows:

W1- Unweeding.

W2-Hand weeding (at 30 and 60 days from planting date).

W3- Harmony extra herbicide (Thifensulfuron) at the rates of $18 \mathrm{gm} / \mathrm{fed}$. (75\% of recommended rate). W4- Harmony extra at the recommended rate ( 24 gm/fed.).

Herbicide Trade name: Harmony Extra

Common Name: Thifensulfuron
Herbicide group: Sulfonylurea

\subsubsection{Seeding systems}

Four seeding treatments were used as follows: S1-drilling, using the recommended seeding rate (60 kg /fed).

S2-drilling, using $150 \%$ of the recommended seeding rate $(90 \mathrm{~kg} / \mathrm{fed})$.

S3-Broadcasting, using $100 \%$ of the recommended seeding rate (70 $\mathrm{kg} / \mathrm{fed})$.

S4-Broadcast, using $150 \%$ of the recommended wheat seeding rate $(105 \mathrm{~kg} / \mathrm{fed})$.

\subsubsection{Nitrogen fertilizer levels}

Two nitrogen fertilizer levels were used as follows:

N1- Application of the recommended dose (100 $\mathrm{kg} \mathrm{N} /$ fed.).

N2-Application of 75\% of the recommended dose.

Nitrogen fertilizer was applied in the form of ammonium nitrate $(33.5 \% \mathrm{~N})$ in eight equal doses. The first dose was applied at 10 days after planting and then each 10 days intervals.

\subsection{Studied characters}

\subsubsection{Weed measurements}

Fresh weight of broad leaved weeds $\left(\mathrm{g} / \mathrm{m}^{2}\right)$ collected at 60 and 90 day after planting date.

\subsubsection{Yield and yield attributes of wheat}

\subsubsection{Number of kernels/spike}

2.2.2.2- Number of spike/ $/ \mathrm{m}^{2}$

\subsubsection{3- Grain yield (ardab/fed.)}

Data were statistically analyzed according to Steel and Torrie (1980). Analysis of variances was performed at each season and combined over the two seasons, the treatment means were compared by Least Significant Differences (LSD) at $p<0.05$ level of significance.

\subsection{Weed measurements \\ 3. RESULTS AND DISCUSSION \\ 3.1.1. Fresh weight of broad leaved weeds $/ \mathrm{m}^{2}$}

Data in Tables $\left(1_{\mathrm{a}, \mathrm{b}}\right)$ indicate that fresh weight of broad leaved weeds significantly decreased with all treatments of weed control at 60 and 90 days after sowing.

The application of Thifensulfuron at $75 \%$ of the recommended dose gave control efficiency of $79.6,79.3$ and $79.5 \%$ at 60 days after sowing and $80.1,90.5$ and $84.5 \%$ control efficiency at 90 days after sowing in the first and second seasons and in combined analysis, respectively.

Application of Thifensulfuron at the recommended rate had control efficiency of 78.8 , 76.5 and $77.8 \%$ at 60 days after sowing and 80.3, 77.9 and $79.3 .8 \%$ at 90 days after sowing in the first and second seasons and in combined analysis, respectively. However, there was no significant 


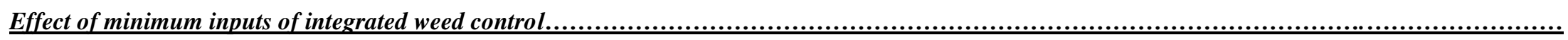

Table $\left(1_{a}\right)$ : Effect of weed control treatments, seeding systems and nitrogen fertilizer on fresh weight of broad leaved weeds $\mathrm{g} / \mathrm{m}^{2}$ at 60 days from sowing in the two seasons and in combined data.

\begin{tabular}{|c|c|c|c|c|c|c|c|c|c|c|c|c|c|c|c|c|}
\hline \multicolumn{7}{|c|}{$2005-2006$} & \multicolumn{5}{|c|}{$2006-2007$} & \multicolumn{5}{|c|}{ Combined data } \\
\hline \multirow{2}{*}{$\begin{array}{l}\text { Seeding } \\
\text { systems }\end{array}$} & \multirow[t]{2}{*}{ Fertilization } & \multicolumn{5}{|c|}{ Weed control } & \multicolumn{5}{|c|}{ Weed control } & \multicolumn{5}{|c|}{ Weed control } \\
\hline & & W1 & W2 & W3 & W4 & Mean & W1 & W2 & W3 & W4 & Mean & W1 & $\mathrm{W} 2$ & W3 & W4 & Mean \\
\hline \multirow[t]{3}{*}{ S1 } & $\mathrm{N} 1$ & 323.8 & 547.1 & 44.7 & 163.7 & 269.8 & 528.0 & 267.8 & 39.4 & 135.0 & 242.6 & 425.9 & 407.5 & 42.0 & 149.4 & 256.2 \\
\hline & N2 & 296.3 & 473.3 & 54.0 & 68.2 & 222.9 & 178.4 & 125.9 & 7.1 & 38.9 & 87.6 & 237.4 & 299.6 & 30.5 & 53.5 & 155.3 \\
\hline & Mean & 310.0 & 510.2 & 49.3 & 115.9 & 246.4 & 353.2 & 196.9 & 23.2 & 87.0 & 165.1 & 331.6 & 353.5 & 36.3 & 101.5 & 205.7 \\
\hline \multirow[t]{3}{*}{ S2 } & $\mathrm{N} 1$ & 343.1 & 117.5 & 29.5 & 63.5 & 138.4 & 313.7 & 98.1 & 216.3 & 51.6 & 169.9 & 328.4 & 107.8 & 122.9 & 57.6 & 154.2 \\
\hline & $\mathrm{N} 2$ & 191.7 & 258.5 & 76.8 & 18.2 & 136.3 & 232.3 & 100.7 & 35.3 & 15.9 & 96.1 & 212.0 & 179.6 & 56.0 & 17.1 & 116.2 \\
\hline & Mean & 267.4 & 188.0 & 53.1 & 40.9 & 137.4 & 273.0 & 99.4 & 125.8 & 33.7 & 133.0 & 270.2 & 143.7 & 89.5 & 37.3 & 135.2 \\
\hline \multirow[t]{3}{*}{ S3 } & N1 & 1031.0 & 290.4 & 27.4 & 90.6 & 359.8 & 447.5 & 185.9 & 65.4 & 53.0 & 188.0 & 739.2 & 238.1 & 46.4 & 71.8 & 273.9 \\
\hline & N2 & 339.9 & 122.3 & 44.4 & 79.9 & 146.6 & 220.7 & 94.1 & 44.8 & 89.8 & 112.3 & 280.3 & 108.2 & 44.6 & 84.8 & 129.5 \\
\hline & Mean & 685.4 & 206.3 & 35.9 & 85.2 & 253.2 & 334.1 & 140.0 & 55.1 & 71.4 & 150.1 & 509.7 & 173.2 & 45.5 & 78.3 & 201.7 \\
\hline \multirow[t]{5}{*}{ S4 } & N1 & 215.9 & 276.7 & 253.8 & 57.2 & 200.9 & 164.2 & 169.4 & 42.0 & 102.6 & 119.6 & 190.1 & 223.0 & 147.9 & 79.9 & 160.2 \\
\hline & N2 & 337.8 & 292.8 & 96.8 & 111.3 & 209.6 & 151.3 & 78.9 & 11.8 & 39.8 & 70.5 & 244.5 & 185.9 & 54.3 & 75.5 & 140.1 \\
\hline & Mean & 276.8 & 284.7 & 175.3 & 84.2 & 205.3 & 157.8 & 124.2 & 26.9 & 71.2 & 95.0 & 217.3 & 204.4 & 101.1 & 77.7 & 150.1 \\
\hline & N1 & 478.4 & 307.9 & 88.8 & 93.8 & 242.2 & 363.4 & 180.3 & 90.8 & 85.6 & 180.0 & 420.9 & 244.1 & 89.8 & 89.7 & 211.1 \\
\hline & N2 & 291.4 & 286.7 & 68.0 & 69.4 & 178.9 & 195.7 & 99.9 & 24.7 & 46.1 & 91.6 & 243.5 & 193.3 & 46.4 & 57.7 & 135.2 \\
\hline Mean & & 384.9 & 297.3 & 78.4 & 81.6 & 210.6 & 279.5 & 140.1 & 57.8 & 65.8 & 135.8 & 332.2 & 218.7 & 68.1 & 73.7 & 173.2 \\
\hline \multicolumn{2}{|c|}{ Control efficiency $\%$} & & 22.8 & 79.6 & 78.8 & & & 49.9 & 79.3 & 76.5 & & & 34.2 & 79.5 & 77.8 & \\
\hline LSD & $\begin{array}{l}\mathrm{W}= \\
\mathrm{S}= \\
\mathrm{WS}= \\
\mathrm{N}= \\
\mathrm{WN}= \\
\mathrm{SN}= \\
\mathrm{WSN}=\end{array}$ & $\begin{array}{c}56.8 \\
56.8 \\
113.7 \\
40.8 \\
81.7 \\
81.7 \\
163.4 \\
\end{array}$ & & & & & $\begin{array}{l}118.7 \\
\text { N.S. } \\
\text { N.S. } \\
36.4 \\
\text { N.S. } \\
\text { N.S. } \\
\text { N.S. }\end{array}$ & & & & & $\begin{array}{c}61.1 \\
40.7 \\
81.4 \\
26.9 \\
53.9 \\
53.9 \\
107.7 \\
\end{array}$ & & & & \\
\hline
\end{tabular}


Table $\left(1_{b}\right)$ : Effect of weed control treatments, seeding systems and nitrogen fertilizer on fresh weight of broad leaved weeds $\mathrm{g} / \mathrm{m}^{2}$ at 90 days from sowing in the two seasons and in combined data.

\begin{tabular}{|c|c|c|c|c|c|c|c|c|c|c|c|c|c|c|c|c|}
\hline \multicolumn{7}{|c|}{$2005-2006$} & \multicolumn{5}{|c|}{ 2006-2007 } & \multicolumn{5}{|c|}{ Combined data } \\
\hline \multirow{2}{*}{$\begin{array}{l}\text { Seeding } \\
\text { systems }\end{array}$} & \multirow[t]{2}{*}{ Fertilization } & \multicolumn{5}{|c|}{ Weed control } & \multicolumn{5}{|c|}{ Weed control } & \multicolumn{5}{|c|}{ Weed control } \\
\hline & & W1 & W2 & W3 & W4 & Mean & $\mathrm{W} 1$ & $\mathrm{~W} 2$ & W3 & W4 & Mean & W1 & W2 & W3 & W4 & Mean \\
\hline \multirow[t]{3}{*}{$\mathrm{S} 1$} & N1 & 471.9 & 554.1 & 113.4 & 245.4 & 346.2 & 896.7 & 265.1 & 114.8 & 92.3 & 342.2 & 684.3 & 409.6 & 114.1 & 168.9 & 344.2 \\
\hline & $\mathrm{N} 2$ & 670.3 & 654.4 & 54.1 & 318.5 & 424.3 & 311.3 & 287.8 & 6.6 & 209.8 & 203.9 & 490.8 & 471.1 & 30.4 & 264.2 & 314.1 \\
\hline & Mean & 571.1 & 604.3 & 83.8 & 282.0 & 385.3 & 604.0 & 276.5 & 60.7 & 151.1 & 273.1 & 587.6 & 440.4 & 72.2 & 216.5 & 329.2 \\
\hline \multirow[t]{3}{*}{$\mathrm{S} 2$} & N1 & 931.9 & 572.9 & 2.0 & 40.3 & 386.8 & 599.1 & 876.6 & 51.3 & 127.8 & 413.7 & 765.5 & 724.8 & 26.7 & 84.1 & 400.3 \\
\hline & $\mathrm{N} 2$ & 473.2 & 328.7 & 2.0 & 55.3 & 214.8 & 427.8 & 354.0 & 2.0 & 2.0 & 196.5 & 450.5 & 341.4 & 2.0 & 28.7 & 205.7 \\
\hline & Mean & 702.6 & 450.8 & 2.0 & 47.8 & 300.8 & 513.5 & 615.3 & 26.7 & 64.9 & 305.1 & 608.0 & 533.1 & 13.6 & 55.4 & 302.9 \\
\hline \multirow[t]{3}{*}{ S3 } & N1 & 544.6 & 169.0 & 542.7 & 62.9 & 329.8 & 498.6 & 241.4 & 80.9 & 129.0 & 237.5 & 521.6 & 205.2 & 311.8 & 95.9 & 283.6 \\
\hline & N2 & 266.9 & 804.6 & 50.8 & 2.0 & 281.1 & 418.7 & 307.6 & 66.6 & 30.2 & 205.8 & 342.8 & 556.1 & 58.7 & 16.1 & 243.5 \\
\hline & Mean & 405.8 & 486.8 & 296.8 & 32.4 & 305.3 & 458.7 & 274.5 & 73.8 & 79.6 & 221.6 & 432.2 & 380.7 & 185.3 & 56.5 & 263.5 \\
\hline \multirow[t]{5}{*}{ S4 } & N1 & 552.3 & 271.7 & 49.9 & 11.3 & 221.3 & 71.2 & 608.3 & 2.0 & 121.6 & 200.8 & 311.8 & 440.0 & 26.0 & 66.5 & 211.1 \\
\hline & N2 & 172.4 & 424.6 & 2.0 & 66.0 & 166.3 & 147.8 & 128.4 & 2.0 & 33.6 & 78.5 & 160.1 & 276.5 & 2.0 & 49.8 & 122.1 \\
\hline & Mean & 362.4 & 348.2 & 26.0 & 38.7 & 193.8 & 109.5 & 368.4 & 2.0 & 77.6 & 139.4 & 235.9 & 358.3 & 14.0 & 58.1 & 166.6 \\
\hline & N1 & 625.2 & 391.9 & 177.0 & 90.0 & 321.0 & 516.4 & 497.9 & 62.3 & 117.7 & 298.5 & 570.8 & 444.9 & 119.6 & 103.8 & 309.8 \\
\hline & $\mathrm{N} 2$ & 395.7 & 553.1 & 27.2 & 110.5 & 271.6 & 326.4 & 269.5 & 19.3 & 68.9 & 170.9 & 361.1 & 411.3 & 23.3 & 89.7 & 221.3 \\
\hline Mean & & 510.4 & 472.5 & 102.2 & 100.3 & 296.4 & 421.4 & 383.7 & 40.8 & 93.3 & 234.8 & 465.9 & 428.1 & 71.5 & 96.8 & 265.6 \\
\hline \multicolumn{2}{|c|}{ Control efficiency $\%$} & & 7.4 & 80.0 & 80.3 & & & 8.9 & 90.3 & 77.9 & & & 8.1 & 84.7 & 79.2 & \\
\hline LSD & $\begin{array}{l}\mathrm{W}= \\
\mathrm{S}= \\
\mathrm{WS}= \\
\mathrm{N}= \\
\mathrm{WN}= \\
\mathrm{SN}= \\
\mathrm{WSN}=\end{array}$ & $\begin{array}{l}142.3 \\
\text { N.S. } \\
\text { N.S. } \\
\text { N.S. } \\
195.2 \\
\text { N.S. } \\
\text { N.S. }\end{array}$ & & & & & $\begin{array}{l}260.9 \\
14.71 \\
\text { N.S. } \\
96.1 \\
\text { N.S. } \\
\text { N.S. } \\
\text { N.S. }\end{array}$ & & & & & $\begin{array}{l}138.0 \\
98.14 \\
\text { N.S. } \\
67.4 \\
\text { N.S. } \\
\text { N.S. } \\
\text { N.S. }\end{array}$ & & & & \\
\hline
\end{tabular}


differences in this trait between unweeding and hand weeding treatment at 90 days after sowing.

Such superiority in control efficiency of broad leaved weeds using Thifensulfuron may be attributed to excellent killing effect against weeds and/or inhibition of weed growth, which inhibit certain basic biochemical processes leading to the death of most weeds .

These results are in agreement with those of ElMetwally and El-Rokiek (2007) who stated that the application of herbicides significantly decreased fresh weight of weeds $/ \mathrm{m}^{2}$.

Data in Tables $\left(1_{\mathrm{a}, \mathrm{b}}\right)$ show that there was significant effect for seeding systems on fresh weight of broad leaved weeds $\mathrm{g} / \mathrm{m}^{2}$ at 60 days after sowing in the $1^{s t}$ season and at 90 days after sowing in the $2^{\text {nd }}$ season and the combined analysis. At the $1^{s t}$ sample, drilling wheat at higher seeding rate significantly decreased weed fresh weight followed by broadcasting at higher rate in the $1^{\text {st }}$ season and in combined analysis. At 90 days after sowing, broadcasting at higher seeding rate produced significant least weed fresh weight. From these results, it could be noted that increasing seeding rate was the main factor in reducing fresh weight of broad-leaved weeds $\mathrm{g} / \mathrm{m}^{2}$ and that may be attributed to more competitiveness of the wheat plants with weeds, thereby reducing the weed growth.

El-Naggar (1996) and Mishra and Tiwari (1999) stated that drilling wheat reduced fresh weight of broad-leaved weeds, compared with broadcasting method.

It is evident that the fresh weight of broadleaved weeds was significantly increased by raising levels of nitrogen from 75 to $100 \%$ of the recommended and that may be due to an increase in vegetative growth of weed plants.

However, Naik et al. (1997) stated that increasing the rate of nitrogen fertilization significantly reduced weed biomass.

The effect of all interactions on the fresh weight of broad leaved weeds at 60 days after sowing was significant in the first season and in combined analysis. At the $2^{\text {nd }}$ sample, only the interaction between weed control treatments and nitrogen levels had a significant effect in the first season only.

At 60 days after sowing, application of Thifensulfuron at low rate with drilling at recommended rate, produced the lowest fresh weight of broad leaved weeds $\mathrm{g} / \mathrm{m}^{2}$ in the combined data. Application of Thifensulfuron at low rate using broadcasting at low rate produced lower fresh weight of broad leaved weeds $\mathrm{g} / \mathrm{m}^{2}$ in the $1^{\text {st }}$ season.

Application of Thifensulfuron at low rate and of $75 \mathrm{~kg} \mathrm{~N} / \mathrm{fed}$. resulted in the lowest fresh weight of broad leaved weeds (Table $1_{\mathrm{a}}$ ).

Evidently sowing wheat at a higher rate using the low rate of nitrogen gave the lowest fresh weight of broad leaved weeds.

Also, the $2^{\text {nd }}$ order interaction revealed that Thifensulfuron at the recommended rate, drilling at higher rate and of $75 \mathrm{~kg} \mathrm{~N} / \mathrm{fed}$. gave the lowest fresh weight of broad leaved weeds in the $1^{s t}$ season and when data were combined at the $2^{s t}$ sample.

\subsection{Yield and yield attributes of wheat 3.2.1. Number of kernels / spike}

Data in Table (2) elucidate that the differences between weed control treatments were significant with regard to the number of kernels /spike in the $1^{s t}$ season as well as when the data were combined.

The application of Thifensulfuron at $24 \mathrm{~g} / \mathrm{fed}$. significantly produced higher values in the number of kernels/ spike i.e., 36.57 and 37.62 in the $1^{\text {st }}$ season and when the data were combined, respectively. While, the differences between two herbicide rates did not reach the significant level.

Hand weeding was significantly higher than unweeding in this trait in the $1^{s t}$ season and when data were combined.

Galal (2003) and Khan et al. (2004) reported that such increase is the number of grains /spike, could be attributed to the effective weed control minimizing weed competion for the available resources of water, nutrients and light.

These results are in agreement with those of El-Naggar (1996), Naik et al. (1997), EL-Hosary et al. (1999), Khan et al. (2004), Pandey and Kumar (2005) and El-Metwally and El-Rokiek (2007).

Data presented in Table (2) show significant effect for seeding systems on this trait. Where, seed drilling at low rate significantly produced higher number of kernels / spike. i.e., 30.19, 41.62 and 35.91 in the $1^{s t}$ and $2^{\text {nd }}$ seasons in combined analysis, respectively. However, broadcasting at the high rate gave lowest numbers of kernels /spike.

It is observed that the increase in seeding rate either drilling or broadcasting reduced number of kernels /spike and that may be due to the dense sowing that could lead to a severe competition among wheat plants for nutrients, water and light, hence, a reduction in photosynthesis could be reflected on spike elongation and development as well as the number of kernels /spike (Galal, 2003). 
Table (2): Effect of weed control treatments, seeding systems and nitrogen fertilizer on number of kernels /spike in the two seasons and in combined data.

\begin{tabular}{|c|c|c|c|c|c|c|c|c|c|c|c|c|c|c|c|c|}
\hline \multirow{3}{*}{$\begin{array}{l}\text { Seeding } \\
\text { systems }\end{array}$} & \multirow{3}{*}{ Fertilization } & \multicolumn{5}{|c|}{$2005-2006$} & \multirow{2}{*}{\multicolumn{5}{|c|}{\begin{tabular}{|c|}
$2006-2007$ \\
Weed control
\end{tabular}}} & \multirow{2}{*}{\multicolumn{5}{|c|}{$\begin{array}{c}\text { Combined data } \\
\text { Weed control } \\
\end{array}$}} \\
\hline & & \multicolumn{5}{|c|}{ Weed control } & & & & & & & & & & \\
\hline & & W1 & W2 & W3 & W4 & Mean & W1 & W2 & W3 & W4 & Mean & W1 & W2 & W3 & W4 & Mean \\
\hline \multirow[t]{2}{*}{ S1 } & N1 & 16.73 & 21.78 & 35.67 & 48.48 & 30.67 & 41.28 & 38.26 & 43.10 & 43.92 & 41.64 & 29.01 & 30.02 & 39.38 & 46.20 & 36.15 \\
\hline & Mean & 16.92 & 27.29 & 34.88 & 41.68 & 30.19 & 39.55 & 40.89 & 44.14 & 41.90 & 41.62 & 28.23 & 34.09 & 39.51 & 41.79 & 35.91 \\
\hline \multirow[t]{3}{*}{ S2 } & N1 & 16.43 & 17.28 & 37.31 & 40.03 & 27.76 & 33.83 & 36.33 & 37.00 & 42.27 & 37.35 & 25.13 & 26.80 & 37.16 & 41.15 & 32.56 \\
\hline & $\mathrm{N} 2$ & 19.58 & 25.10 & 33.48 & 35.95 & 28.53 & 30.98 & 31.15 & 34.62 & 42.83 & 34.89 & 25.28 & 28.13 & 34.05 & 39.39 & 31.71 \\
\hline & Mean & 18.00 & 21.19 & 35.39 & 37.99 & 28.14 & 32.40 & 33.74 & 35.81 & 42.55 & 36.12 & 25.20 & 27.46 & 35.60 & 40.27 & 32.13 \\
\hline \multirow{2}{*}{ S3 } & $\mathrm{N} 2$ & 20.69 & 20.30 & 35.34 & 27.95 & 26.07 & 39.33 & 37.23 & 46.57 & 40.40 & 40.88 & 30.01 & 28.76 & 40.95 & 34.18 & 33.48 \\
\hline & Mean & 22.39 & 23.64 & 36.03 & 32.99 & 28.76 & 38.94 & 40.65 & 43.35 & 37.29 & 41.31 & 33.17 & 32.14 & 39.69 & 35.14 & 35.04 \\
\hline \multirow[t]{5}{*}{ S4 } & N1 & 15.96 & 25.63 & 30.48 & 33.61 & 26.42 & 32.72 & 31.75 & 40.37 & 31.04 & 33.97 & 24.34 & 28.69 & 35.42 & 32.33 & 30.19 \\
\hline & N2 & 17.44 & 24.15 & 32.93 & 33.63 & 27.04 & 29.87 & 35.80 & 35.03 & 34.93 & 33.91 & 23.65 & 29.97 & 33.98 & 34.28 & 30.47 \\
\hline & Mean & 16.70 & 24.89 & 31.70 & 33.62 & 26.73 & 31.29 & 33.77 & 37.70 & 32.98 & 33.94 & 24.00 & 29.33 & 34.70 & 33.30 & 30.33 \\
\hline & N1 & 18.31 & 22.91 & 35.04 & 40.04 & 29.08 & 36.59 & 37.60 & 40.15 & 37.85 & 38.07 & 28.70 & 30.26 & 37.60 & 38.94 & 33.87 \\
\hline & $\mathrm{N} 2$ & 18.70 & 25.59 & 33.96 & 33.10 & 27.84 & 34.50 & 36.92 & 40.35 & 39.51 & 37.82 & 26.60 & 31.26 & 37.16 & 36.30 & 32.83 \\
\hline Mean & & 18.50 & 24.25 & 34.50 & 36.57 & 28.46 & 36.79 & 37.26 & 40.25 & 38.68 & 38.25 & 27.65 & 30.76 & 37.38 & 37.62 & 33.35 \\
\hline
\end{tabular}


Some researchers found that the number of kernels/spike significantly decreased as seeding rate increased (Galal, 2003; Dixit and Gupta, 2004; Lloveras et al., 2004 and Schillinger, 2005).

Number of kernels / spike of drilled wheat was greater than of broadcasted one (Hassan et al., 2003; Dixit and Gupta, 2004 and Khan et al., 2007).

Results tabulated in Table (2) show that the number of kernels /spike was insignificantly affected by increasing levels of nitrogen fertilizer in both tested seasons and in combined analysis. Similarly Mahrous et al. (1998) and Sardana, et al. (2002) agreed on these results.

Data presented in Table (2) indicate that the number of kernels/spike was significantly affected by the interaction between weed control methods and seeding systems. Application of Thifensulfuron at the recommended dose with drilling at a low rate produced considerable increase in the number of kernels/spike in the $1^{s t}$ season and combined data. While, in the $2^{\text {nd }}$ season, spraying Thifensulfuron at $18 \mathrm{~g} / \mathrm{fed}$. with drilling at the recommended rate gave the highest number of kernels/spike (44.14). However, unweeding the crop broadcasted at the higher rate recorded the least number of kernels/spike.

The interaction between weed control treatments and nitrogen levels significantly affected the number of kernels/spike in the $1^{\text {st }}$ season. Higher value was detected by spraying Thifensulfuron at $24 \mathrm{~g} / \mathrm{fed}$. and $100 \mathrm{~kg} \mathrm{~N} / \mathrm{fed}$. (40.04).

The $2^{\text {nd }}$ order interaction of the tested factors significantly affected number of kernels/spike in the $1^{\text {st }}$ season and in combined analysis. Applying Thifensulfuron at the recommended dose with drilling at a low rate and fertilizing with recommended rate of nitrogen gave the highest number of kernels/spike (48.48 and 46.20 in the $1^{\text {st }}$ season and in combined analysis, respectively). 3.2.2. Number of spikes $/ \mathrm{m}^{2}$

Number of wheat spikes $/ \mathrm{m}^{2}$ was significantly influenced by weed control, seeding systems, while, nitrogen fertilizer levels significantly affected this trout in the $1^{s t}$ season and in combined analysis only (Table 3). Spraying Thifensulfuron at $18 \mathrm{gm} / \mathrm{fed}$. had the highest numbers of spikes $/ \mathrm{m}^{2}$ i.e., 274.7 and 320.6 spikes in the $1^{s t}$ season and when data were combined, respectively. While, in the $2^{\text {nd }}$ season the rate of 24 $\mathrm{gm} / \mathrm{fed}$. gave the highest number (368.2 spikes) of spikes $/ \mathrm{m}^{2}$. However, no significant differences were observed between both rates of this herbicide.
Difference between unweeding and hand weeding in this trait was insignificant in the $1^{s t}$ season and in combined analysis.

Superiority in the number of spikes $/ \mathrm{m}^{2}$ with Thifensulfuron could be referred to the great reduction of weed competition for light and soil resources leading to improved the tillering capacity (Khan et al., 2004).

These results are in concordance with those obtained by Khan et al. (2004) and El-Metwally and El-Rokiek (2007).

Seeding system had significant effect on spikes $/ \mathrm{m}^{2}$ in both seasons and in combined data. The highest number of spikes $/ \mathrm{m}^{2}$ was recorded when high seeding rate was broadcasted. It could be concluded that increasing seeding rate at the same sowing method increased the number of spikes $/ \mathrm{m}^{2}$ and that may be attributed to the increase of wheat plant density (Galal, 2003) or growth attributes (El-Hosary et al., 1999). However, drilling with recommended rate of wheat seeds gave the least values in the numbers of spike $/ \mathrm{m}^{2}$.

These results are in agreement with those of Carr et al. (2003); Lloveras et al. (2004); Haikel and El-Melegy, 2005; Schillinger, 2005; GuillenPortal et al. (2006); Lithourgidis et al. (2006) and Mehrvar and Asadi (2006) who reported that number of spike $/ \mathrm{m} 2$ was significantly increased as seeding rate was increased.

Concerning nitrogen fertilizer; significant increase in the number of spikes $/ \mathrm{m}^{2}$ was obtained with increasing nitrogen fertilizer from 75 to $100 \mathrm{~kg}$ N/fed., these increases estimated by 19.1 and $11.0 \%$ over those with $75 \mathrm{~kg} \mathrm{~N} /$ fed. in the $1^{\text {st }}$ season and when data were combined, respectively.

Abo-Shetaia and Abd El-Gawad, (1995), Abdul Galil et al. (1997)and Sowires (2000) reported that the reasons of increment in the number of spikes $/ \mathrm{m}^{2}$ with increasing nitrogen levels might be due to the fact that nitrogen is an essential element which plays an important role in building new meristemic cells, promotes tillering in cereal crops. They added that nitrogen fertilizer increases photosynthesis activity which encourages formation of more spikes /plant and turns to increase the number of spikes /unit area.

These findings are supported by those of many workers including Abd EL-Maksoud (2002); Ashmawy and Abo-Warda (2002); Mowafy (2002); Saleh (2002a \& b); Sardana et al. (2002) and Simon et al. (2002).

The interaction between seeding systems and nitrogen fertilizer levels significantly affected 
Table (3): Effect of weed control treatments, seeding systems and nitrogen fertilizer on number of spike /m2 in the two seasons and in combined data.

\begin{tabular}{|c|c|c|c|c|c|c|c|c|c|c|c|c|c|c|c|c|}
\hline \multirow{3}{*}{$\begin{array}{l}\text { Seeding } \\
\text { systems }\end{array}$} & \multirow{3}{*}{ Fertilization } & \multicolumn{5}{|c|}{ 2005-2006 } & \multirow{2}{*}{\multicolumn{5}{|c|}{$\frac{2006-2007}{\text { Weed control }}$}} & \multirow{2}{*}{\multicolumn{5}{|c|}{$\begin{array}{c}\text { Combined data } \\
\text { Weed control }\end{array}$}} \\
\hline & & & & eed con & & & & & & & & & & & & \\
\hline & & W1 & W2 & W3 & W4 & Mean & W1 & $\mathrm{W} 2$ & W3 & W4 & Mean & W1 & W2 & W3 & W4 & Mean \\
\hline \multirow[t]{3}{*}{ S1 } & N1 & 202.2 & 180.6 & 245.8 & 309.1 & 234.4 & 275.0 & 226.8 & 324.5 & 258.3 & 271.1 & 238.6 & 203.7 & 285.2 & 283.7 & 252.8 \\
\hline & $\mathrm{N} 2$ & 175.4 & 147.2 & 227.1 & 280.3 & 207.5 & 266.3 & 341.8 & 360.0 & 375.8 & 335.9 & 220.8 & 244.5 & 293.6 & 328.0 & 271.7 \\
\hline & Mean & 188.8 & 163.9 & 236.5 & 294.7 & 221.0 & 270.6 & 284.3 & 342.3 & 317.0 & 303.5 & 229.7 & 224.1 & 289.4 & 305.8 & 262.2 \\
\hline \multirow[t]{3}{*}{ S2 } & N1 & 212.8 & 234.3 & 358.5 & 314.8 & 280.1 & 315.5 & 337.8 & 362.3 & 465.0 & 370.1 & 264.1 & 286.0 & 360.4 & 389.9 & 325.1 \\
\hline & $\mathrm{N} 2$ & 204.1 & 224.3 & 294.4 & 234.3 & 239.3 & 266.5 & 372.5 & 327.5 & 319.8 & 321.6 & 235.3 & 298.4 & 311.0 & 277.0 & 280.4 \\
\hline & Mean & 208.4 & 229.3 & 326.5 & 274.6 & 259.7 & 291.0 & 355.1 & 344.9 & 392.4 & 345.8 & 249.7 & 292.2 & 335.7 & 333.5 & 302.8 \\
\hline \multirow[t]{3}{*}{ S3 } & N1 & 231.2 & 201.3 & 265.7 & 271.4 & 242.4 & 247.0 & 435.5 & 381.3 & 407.3 & 367.8 & 239.1 & 318.4 & 323.5 & 339.3 & 305.1 \\
\hline & $\mathrm{N} 2$ & 138.0 & 188.6 & 197.8 & 220.8 & 186.3 & 215.3 & 262.1 & 301.0 & 304.8 & 270.8 & 176.7 & 225.4 & 249.4 & 262.8 & 228.5 \\
\hline & Mean & 184.6 & 194.9 & 231.7 & 246.1 & 214.3 & 231.2 & 348.8 & 341.1 & 356.0 & 319.3 & 207.9 & 271.9 & 286.4 & 301.1 & 266.8 \\
\hline \multirow[t]{5}{*}{ S4 } & N1 & 251.9 & 255.6 & 334.4 & 262.2 & 276.0 & 365.4 & 385.3 & 374.8 & 392.5 & 379.5 & 308.6 & 320.4 & 354.6 & 327.4 & 327.7 \\
\hline & $\mathrm{N} 2$ & 195.5 & 208.7 & 274.3 & 257.6 & 234.0 & 335.2 & 288.0 & 501.1 & 422.0 & 386.6 & 265.4 & 248.4 & 387.7 & 339.8 & 310.3 \\
\hline & Mean & 223.7 & 232.2 & 304.3 & 259.9 & 255.0 & 350.3 & 336.6 & 437.9 & 407.3 & 383.0 & 287.0 & 284.4 & 371.1 & 333.6 & 319.0 \\
\hline & N1 & 224.5 & 217.9 & 301.1 & 289.4 & 258.2 & 300.7 & 346.3 & 360.7 & 380.8 & 347.1 & 262.6 & 282.1 & 330.9 & 335.1 & 302.7 \\
\hline & $\mathrm{N} 2$ & 178.3 & 192.2 & 248.4 & 248.3 & 216.8 & 270.8 & 316.1 & 372.4 & 355.6 & 328.7 & 224.5 & 254.1 & 310.4 & 301.9 & 272.7 \\
\hline Mean & & 201.4 & 205.1 & 274.7 & 268.8 & 237.5 & 285.8 & 331.2 & 366.5 & 368.2 & 337.9 & 243.6 & 268.1 & 320.6 & 318.5 & 287.7 \\
\hline \multirow[t]{7}{*}{ LSD } & $\mathrm{W}=$ & 54.10 & & & & & 35.05 & & & & & 29.94 & & & & \\
\hline & $S=$ & 34.23 & & & & & 30.28 & & & & & 22.61 & & & & \\
\hline & $\mathrm{WS}=$ & N.S. & & & & & N.S. & & & & & N.S. & & & & \\
\hline & $\mathrm{N}=$ & 17.03 & & & & & N.S. & & & & & 13.24 & & & & \\
\hline & $\mathrm{WN}=$ & N.S. & & & & & N.S. & & & & & N.S. & & & & \\
\hline & $\mathrm{SN}=$ & N.S. & & & & & 41.66 & & & & & 26.48 & & & & \\
\hline & $\mathrm{WSN}=$ & N.S. & & & & & 83.32 & & & & & 52.96 & & & & \\
\hline
\end{tabular}


number of spikes $/ \mathrm{m} 2$ in the $2^{\text {nd }}$ season and the combined analysis.

The $2^{\text {nd }}$ order interaction among the three tested factors significantly affected number of spikes $/ \mathrm{m}^{2}$ in the $2^{\text {nd }}$ season and the combined analysis. Where, applying thifensulfuron at the recommended dose with drilling at high rate and adding $100 \mathrm{~kg} \mathrm{~N} /$ fed. recorded the highest number of spikes $/ \mathrm{m}^{2}$ (465.0 and 389.9 spikes $/ \mathrm{m}^{2}$ ) in the $2^{\text {nd }}$ season and the combined data, respectively. However, the lowest numbers of spikes $/ \mathrm{m} 2$ were recorded when unweeding check with broadcasting at the recommended rate and adding $75 \mathrm{~kg} \mathrm{~N} / \mathrm{fed}$.

\subsubsection{Grain yield (Ardabs/fed)}

Data presented in Table (4) indicate significant effect for weed control treatments on grain yield /fed. in both seasons and combined data.

It is also observed that the weed control treatments could be separated into two groups according to their effect on grain yield with no significant differences among treatments of each group. The $1^{\text {st }}$ group, with significant increase in grain yield, included the application of herbicide Thifensulfuron at 18 or $24 \mathrm{gm} / \mathrm{fed}$. The second group included hand weeding and unweeded check.

Spraying Thifensulfuron in wheat field at the lower rate $(75 \%$ of recommended rate) produced clear and significant increase in wheat grain yield compared to unweeded check ( $9.24,9.35$ and $9.30 \mathrm{ardabs} / \mathrm{fed}$. ) giving a high relative yield of $(229.3,155.8$ and $185.3 \%)$ ) through the $1^{s t}, 2^{\text {nd }}$ seasons and the combined data. Applying Thifensulfuron at the recommended dose (24 $\mathrm{gm} / \mathrm{fed}$. ) yielded also the highest significantly grain yield which were $8.91,9.80$ and 9.36 ardabs/fed. ) showing relative yield of 221.1, 163.3 and 186.5 compared to unweeded check.

Unweeding check gave the least grain yield of 4.0, 6.0 and 5.0 ardabs/fed. and that may be due to weed competition which reflected on crop growth leading to less yield attributes.

It is clearly observed that there were no significant differences in grain yield resulted from the two rates of herbicide Thifensulfuron.

Therefore, it could be recommended that, under Elbostan conditions and when chemical weed control is needed, the application of Thifensulfuron at the rate of $18 \mathrm{gm} / \mathrm{fed}$. is effective and more economic in controlling broad leaved weeds in wheat fields.

The superiority of herbicide in maximizing grain yield of wheat may be due to effective weed control (Khan et al., 2004) and the availability of resources to wheat plants under minimum weed competition (Khan et al., 2003a and b) which could lead to more tillers number $/ \mathrm{m}^{2}$, reflecting on increasing the number of spikes $/ \mathrm{m}^{2}$ and the number of kernels /spike .

These results are in agreement with those of Adamczewski and Matysiak (2005); Adamczewski et al. (2005) and El-Metwally and El-Rokiek (2007) who reported the superiority of applying Thifensulfuron in controlling broad leaved weeds in wheat fields. On the other hand, some researchers recorded different findings (Khan et al., 2001; Galal (2003); Pandey and Kumar, 2005) who reported that hand weeding, gave a positive effect on wheat grain yield compared to unweeding.

Seeding systems did not significantly affect wheat grain yield during the two seasons or when data were combined (Table 4). These results are in harmony with those achieved by Saleh (2002 b); Hassan et al. (2003); Dixit and Gupta, 2004; Schillinger (2005); Lithourgidis et al. (2006) and Otteson et al. (2007) who reported that seeding systems did not significantly affect grain yield of wheat.

Data presented in Table (4) indicate that increasing the level of nitrogen fertilizer significantly increased grain yield in the two seasons and the combined analysis. Increasing nitrogen fertilizer levels, from 75 to $100 \mathrm{~kg} \mathrm{~N} / \mathrm{fed}$., had a significant increase in grain yield. This result may be due the positive effect of nitrogen level in increasing the number of kernels /spike, the number of spikes $/ \mathrm{m}^{2}$. Similar results were obtained by Abd EL-Maksoud (2002); Ashmawy and Abo-Warda (2002); Mahajan et al. (2002); Mowafy (2002); Saleh (2002 a and b); Sardana et al. ( 2002); Simon et al. (2002); Herrera et al. (2007) and Weber et al. (2008).

The interaction between weed control treatments and seeding systems significantly affected grain yield of wheat. Spraying Thifensulfuron at $24 \mathrm{gm} / \mathrm{fed}$. with drilling at higher rate gave higher grain yield $(11.52$ and 10.11 ardabs/fed. in the second season and in combined analysis, respectively). On the other hand, lower grain yield was recorded using hand weeding with drilling at the recommend rate (3.48, 5.23 and 4.36 ardabs/fed. in the first and second seasons and when data were combined, respectively).

The interaction between weed control treatments and nitrogen fertilizer levels significantly affected grain yield in both seasons. Applying Thifensulfuron at the low dose with 
Table (4): Effect of weed control treatments, seeding systems and nitrogen fertilizer on grain yield (ardab /fed.) in the two seasons and in combined data.

\begin{tabular}{|c|c|c|c|c|c|c|c|c|c|c|c|c|c|c|c|c|}
\hline \multirow{3}{*}{$\begin{array}{l}\text { Seeding } \\
\text { systems }\end{array}$} & \multirow{3}{*}{ Fertilization } & \multicolumn{5}{|c|}{ 2005-2006 } & \multicolumn{5}{|c|}{$2006-2007$} & \multicolumn{5}{|c|}{ Combined data } \\
\hline & & \multicolumn{5}{|c|}{ Weed control } & \multicolumn{5}{|c|}{ Weed control } & \multicolumn{5}{|c|}{ Weed control } \\
\hline & & W1 & $\mathrm{W} 2$ & W3 & W4 & Mean & $\mathrm{W} 1$ & $\mathrm{~W} 2$ & W3 & W4 & Mean & $\mathrm{W} 1$ & $\mathrm{~W} 2$ & W3 & W4 & Mean \\
\hline \multirow[t]{3}{*}{ S1 } & N1 & 3.54 & 3.11 & 9.97 & 11.57 & 7.05 & 6.21 & 5.68 & 9.79 & 9.87 & 7.89 & 4.88 & 4.39 & 9.88 & 10.72 & 7.47 \\
\hline & $\mathrm{N} 2$ & 3.69 & 3.86 & 7.53 & 7.67 & 5.69 & 5.80 & 4.77 & 11.79 & 9.83 & 8.05 & 4.74 & 4.32 & 9.66 & 8.75 & 6.87 \\
\hline & Mean & 3.61 & 3.48 & 8.75 & 9.62 & 6.37 & 6.01 & 5.23 & 10.79 & 9.85 & 7.97 & 4.81 & 4.36 & 9.77 & 9.73 & 7.17 \\
\hline \multirow[t]{3}{*}{$\mathrm{S} 2$} & N1 & 3.01 & 4.66 & 11.28 & 9.79 & 7.19 & 7.04 & 6.91 & 9.92 & 11.99 & 8.97 & 5.02 & 5.79 & 10.60 & 10.89 & 8.08 \\
\hline & $\mathrm{N} 2$ & 5.64 & 4.92 & 9.07 & 7.63 & 6.81 & 4.80 & 5.00 & 8.17 & 11.04 & 7.25 & 5.22 & 4.96 & 8.62 & 9.33 & 7.03 \\
\hline & Mean & 4.33 & 4.79 & 10.18 & 8.71 & 7.00 & 5.92 & 5.96 & 9.05 & 11.52 & 8.11 & 5.12 & 5.37 & 9.61 & 10.11 & 7.55 \\
\hline \multirow[t]{3}{*}{ S3 } & N1 & 4.72 & 4.63 & 9.52 & 8.85 & 6.93 & 6.61 & 7.33 & 9.21 & 8.43 & 7.90 & 5.67 & 5.98 & 9.36 & 8.64 & 7.41 \\
\hline & $\mathrm{N} 2$ & 3.07 & 3.99 & 8.40 & 7.80 & 5.81 & 5.58 & 6.01 & 8.17 & 9.66 & 7.35 & 4.32 & 5.00 & 8.29 & 8.73 & 6.58 \\
\hline & Mean & 3.89 & 4.31 & 8.96 & 8.32 & 6.37 & 6.10 & 6.67 & 8.69 & 9.05 & 7.62 & 4.99 & 5.49 & 8.83 & 8.68 & 7.00 \\
\hline \multirow[t]{5}{*}{ S4 } & N1 & 5.08 & 6.16 & 9.22 & 9.32 & 7.45 & 7.13 & 6.90 & 8.47 & 8.63 & 7.78 & 6.10 & 6.53 & 8.85 & 8.98 & 7.61 \\
\hline & N2 & 3.51 & 3.78 & 8.90 & 8.67 & 6.21 & 4.84 & 5.84 & 9.31 & 8.95 & 7.24 & 4.18 & 4.81 & 9.10 & 8.81 & 6.72 \\
\hline & Mean & 4.29 & 4.97 & 9.06 & 9.00 & 6.83 & 5.98 & 6.37 & 8.89 & 8.79 & 7.51 & 5.14 & 5.67 & 8.98 & 8.89 & 7.17 \\
\hline & N1 & 4.09 & 4.64 & 10.00 & 9.88 & 7.15 & 6.75 & 6.71 & 9.35 & 9.73 & 8.13 & 5.42 & 5.67 & 9.67 & 9.81 & 7.64 \\
\hline & $\mathrm{N} 2$ & 3.98 & 4.14 & 8.47 & 7.94 & 6.13 & 5.25 & 5.40 & 9.36 & 9.87 & 7.47 & 4.62 & 4.77 & 8.92 & 8.91 & 6.80 \\
\hline Mean & & 4.03 & 4.39 & 9.24 & 8.91 & 6.64 & 6.00 & 6.06 & 9.35 & 9.80 & 7.80 & 5.02 & 5.22 & 9.30 & 9.36 & 7.22 \\
\hline \multirow[t]{7}{*}{ LSD } & $\mathrm{W}=$ & 1.08 & & & & & 0.72 & & & & & 0.60 & & & & \\
\hline & $S=$ & N.S. & & & & & N.S. & & & & & N.S. & & & & \\
\hline & $\mathrm{WS}=$ & N.S. & & & & & 1.34 & & & & & 1.04 & & & & \\
\hline & $\mathrm{N}=$ & 0.39 & & & & & 0.41 & & & & & 0.28 & & & & \\
\hline & $\mathrm{WN}=$ & 0.78 & & & & & 0.82 & & & & & N.S. & & & & \\
\hline & $\mathrm{SN}=$ & N.S. & & & & & 0.82 & & & & & N.S. & & & & \\
\hline & $\mathrm{WSN}=$ & 1.56 & & & & & N.S. & & & & & 1.11 & & & & \\
\hline
\end{tabular}


fertilizing with the recommended rate of nitrogen or spraying Thifensulfuron at the recommended dose with fertilizing with low rate of nitrogen gave higher grain yield in the first and second season. However, unweeding check with low rate of nitrogen recorded lower grain yield of 3.98, 5.25 and 4.6 ardabs/fed. in the first and second season and in combined analysis, respectively.

The interaction between seeding systems and nitrogen fertilizer levels significantly affected grain yield in the second season only. Using drilling at high rate with adding $100 \mathrm{~kg} \mathrm{~N} / \mathrm{fed}$. gave higher grain yield of 8.97 and 8.08 ardabs/fed. in the second seasons and in combined analysis, respectively.

The significant effects of the interaction among three tested factors on grain yield were observed in the first season and when the data were combined (Table 4). The application of Thifensulfuron at the recommended dose with drilling at low rate and fertilizing with the recommended rate of nitrogen produced the highest grain yield (11.57 ardabs/fed.) in the first season. Also, spraying Thifensulfuron at $24 \mathrm{~g} / \mathrm{fed}$ with the drilling at high rate and adding $100 \mathrm{~kg}$ $\mathrm{N} /$ fed gave highest grain yield 11.99 and 10.89 ardabs/fed. in the second season and in combined analysis.

It can be concluded that applying Thifensulfuron at both tested rates gave an excellent control efficiency on broad leaved weeds. Since there was no significant difference between both rates of Thifensulfuron herbicide, therefore it could be recommended that using the lower rate of herbicide in controlling broad leaved weeds in wheat fields because it was effective and more economic.

There was a significant effect for seeding systems on fresh weight of broad leaved weeds, where it was noted that increasing seeding rates of wheat reduced fresh weight of broad leaved weeds as well as it reduced the number of kernels /spike, but it had an increase in the number of spikes $/ \mathrm{m}^{2}$ thus grain yield was not significantly affected. While, combined data indicate that the interaction between weed control treatments and seeding systems significantly affected grain yield of wheat. Spraying Thifensulfuron at 18 or $24 \mathrm{~g} / \mathrm{fed}$ with drilling at a high rate gave better grain yield.

Increasing nitrogen levels caused significant increase in broad leaved weeds and the number of spikes $/ \mathrm{m}^{2}$ and consequently led to an increase in grain yield.

\section{REFERENCES}

Abd Al-Maksoud M. F. (2002). Response of some wheat cultivars to biofertilizer and nitrogen fertilizer levels. Zagazig J. Agric. Res., 29(3):891-905.

Abdul Galil A. A. , Gomaa M. A., Geweifel H. G. M. and Atta Y. E. M. (1997). Response of yield and some grain quality criteria in wheat to nitrogen and phosphorus fertilization . Zagazig J. Agric. Res., 24(4): 595-613.

Abo-Shetaia A. M. and Abd EL- Gawad A. A. (1995). Effect of winter withholding irrigation and $\mathrm{N}$ - fertilization on yield of two wheat cultivars . Annals Agric. Sci., Ain Shams Univ., Cairo, 40(1):177-193.

Adamczewski K. and Matysiak R. (2005). The effects and benefits of adjuvants used with sulfonylourea herbicides. Progress in Plant Protection. 45(1): 17-24.

Adamczewski K., Gowacki G. and Matysiak R. (2005). Influence of adjuvants on enhance weed control efficacy of Harmony Extra 75 WG in winter and spring wheat. Progress in Plant Protection. 45(2): 561-564.

Ashmawy F. and Abo-Warda A. M. A. (2002). Response of some wheat cultivars to different seeding rates and nitrogen fertilization levels in sand soil. Egypt J. Appl. Sci., 17(10):136-157.

Azad B.S. and Singh H. (1997). Effect of weedcontrol measures and nitrogen on productivity of wheat (Triticum aestivum). Indian J. Agro. 42(1):98-130.

Carr P.M., Horsley R.D. and Poland W.W. (2003) Tillage and seeding rate effects on wheat cultivars. II. yield components. Crop Sci., 43(1): 210-218.

Dixit A. K. and Gupta A. K. (2004). Influence of methods of sowing and seed rates on growth and yield of wheat (Triticum aestivum) under different dates of sowing. Environment and Ecology. 22(Spl-3): 407410.

El-Hosary A.A., El-Nagger H.M., Abd El-Hamid M.M. and Shebl S.M. (1999). The effects of wheat cultivars, seeding rates and weed control treatments on wheat yield and its components. Annals Agric. Sci. Moshtohor, Univ., 37 (2) 805-820.

El-Metwally I. M. and El-Rokiek K.G. (2007). Response of wheat plants and accompanied weeds to some new herbicides alone or combined in sequence. Arab Univ. J. Agric. 
Sci., Ain Shams Univ., Cario. 15(2): 513525.

El-Naggar H. M. M. (1996). Response of wheat and associated weeds to some weed control treatments and sowing methods. Annals of Agric. Sci., Moshtohor. 34(3):935-950.

Galal A.H. (2003). Response of wheat and its associated weeds to sowing methods, seeding rates and weed control treatments. Assiut J. Agric. Sci., 34(5):77-98.

Guillen-Portal F.R., Stougaard R.N., Xue Q. and Eskridge K.M. (2006). Compensatory mechanisms associated with the effect of spring wheat seed size on wild oat competition. Crop Sci. 46:935-945.

Haikel M.A. and El-Melegy A.M. (2005). Effect of irrigation requirements, seeding rates and bio-mineral fertilizer on wheat productivity in newly reclaimed soil under sprinkler irrigation system. Journal of Productivity and Development. 10(1):113-134.

Hassan G., Faiz B., Marwat K. B. and Khan M. (2003). Effects of planting methods and tank mixed herbicides on controlling grassy and broadleaf weeds and their effect on wheat cv. Fakhr-e- Sarhad. Pakistan Journal of Weed Science Research. 9(1/2): 1-11

Herrera J. M., Stamp O. and Liedgens M. (2007). Interannual varialility in root growth of spring wheat (Triticum aestivum L.) at low and high nitrogen supply. Europ J. Agron. 26:317-326.

Hucl P. (1998). Response to weed control by four spring wheat genotypes differing in competitive ability. Canadian J. Plant Sci., 78(1): 171-173.

Khan N. U., Khan S. U., Hassan G., Khakwani A. A. and Nawaz Q. (2001) Studies on chemical weed control measures in wheat (Triticum aestivum L.). J. of Biological Sci. 1(7) : 584-586.

Khan I., Hassan G., Khan M.A. and Khan M.I. (2003a). Efficacy of some new herbicidal molecules on weed density and yield components of wheat. Pak. J. Weed Sci. Res. 9(3\&4):141-146.

Khan M. I., Hassan G., Khan I. A. and Khan I (2003b) Studies on Post-emergent chemical weed control in wheat (Triticum aestivum L.). Pak. J. Weed Sci. Res 9(3\&4):147-152.

Khan M.I., Hassan G., Khan I.A. and Khan I. (2004). Studies on chemical weed control in wheat (Triticum aestivum L.). Pak. J. Weed Sci. Res. 10 (3-4):113-118.
Khan A., Arif M., Shah A., Ali S., Hussain Z. and Khan S. (2007). Evaluation of planting methods for grain yield and yield components of wheat. Sarhad Journal of Agriculture. 23(3): 561-564.

Lithourgidis A.S., Dhima K.V., Damalas C.A., Vasilakoglou I.B. and Eleftherohorinos I.G. (2006). Tillage effects on wheat emergence and yield at varying seeding rates, and on labor and fuel consumption. Crop Sci. 46:1187-1192.

Lloveras J., Manent J., Viudas J., Lopez A. and Santiveri P. (2004) Seeding rate influence on yield and yield components of irrigated winter wheat in a Mediterranean climate. Agron. J. 96:1258-1265.

Mahajan K. K., Kumar S., Dev S. P., Bhardwaj K. K. R. and Gupta S. P. (2002). Evaluation of industrial wastes in wheat(Triticum aestivum) - maize (Zea mays) cropping system in mid-hills sub- humid zone of himachal Pradesh. Indian J. Agric. Sci., 72(5):257-259.

Mahrous M. A., Eisa M. S. and Abd-Alla A. A. (1998). Effect of intercropping wheat with lentil at varying nitrogen fertilization rates on yield and their components. Annals Agric. Sci. Moshtohor, Univ., 36 (1) 61-69.

Mehasen S.A.S. (1999). Wheat yield as affected by bio and nitrogen fertilization. Annals Agric. Sci. Moshtohor, Univ.,37(1):157170.

Mehrvar M. R. and Asadi H. (2006). Agronomical and economical assessment of planting methods and seeding rates in irrigated wheat (Triticum aestivum L.). Journal of Agronomy. 5(4): 626-633.

Mishra A. K. and Tiwari R. C. (1999). Effect of seeding method and fertilizer application on weed biomass and yield of wheat (Triticum aestivum). Indian Journal of Agronomy. 44(2): 353-356.

Mowafy S.A.E. (2002). Effect of organic manuring and splitting of different levels of nitrogen on wheat under sprinkler irrigation in sandy soils. Zagazig J. Agric. Res., 29 (1): 51-72.

Naik K. R., Gogulwar N. M. and Tiwari J. P. (1997). Effect of weed control under different moisture regime and nitrogen on wheat (Triticum aestivum). Indian J. Agro. 42 (2): 300-305.

Nisha C., Harpal S., Tripathi H.P., Chopra N. and Singh H. (1999). Critical period of weed crop competition in wheat (Triticum 
aestivum L.). Indian J. Weed Sci., 31(3-4): 151-154.

Otteson B. N., Mergoum M., and Ransom J. K. (2007). Seeding rate and nitrogen management effects on spring wheat yield and yield components. Agro. J. 99 (6): 1615-1621.

Pandey I.B. and Kumar K. (2005). Response of wheat (Triticum aestivum) to seeding methods and weed management. Indian J. Agron. 50 (1): 48-51.

Saleh M. E. (2002a). Wheat productivity as affected by sources and levels of nitrogen fertilizer. Zagazig J. Agric. Res., 28(2):239-250.

Saleh M. E. (2002b). Response of two wheat cultivars to seeding rate and nitrogen level. Zagazig J. Agric. Res., 29 (5):1367-1378.

Sardana V., Sharma S. K. and Randhawa A. S. (2002). Peformance of wheat (Triticum aestivum L.) varieties under different sowing dates and nitrogen levels in subMontane region of Punjab. Indian J. Agron. 47 (3):372-377.

Schillinger W.F. (2005). Tillage method and sowing rate relations for dryland spring wheat, barley, and oat. Crop Sci. 45:26362643.
Simon M. R., Perello A. E., Cordo C.A. and Struik P.C. (2002). Influence of Septoria

tritici on yield, yield components, and test weight of wheat under two nitrogen fertilization conditions. Crop Sci., 42: 1974-1981.

Singh V.P. (1997). Response of rainfed wheat

(Triticum aestivum) to nitrogen and weedcontrol methoed at low hill and valley situation. Indian J. Agro. 42 (2): 288-292.

Sowires E. S. (2000). Yield and yield attributes of wheat in relation to $\mathrm{N}$ - fertilization and withholding an irrigation at different stages of growth. Annals Agric. Sci. Ain- Shams, Univ., Cairo, 45(2)439-452.

Steel R.C.D. and Torrie J.H. (1980). Principles and Procedures of Statistics. A Biometrical Approach. 2nd ed. Mc Graw- Hill Book Co., Inc., New York, USA.

Tiwari R.P. and Parihar S.S. (1997). Weed management in wheat (Triticum aestivum L.). Indian J. Agron. 42 (4): 726-728.

Weber E. A., Graeff S., Koller W. D., Hermann W., Merkt N. and Claupein W. (2008). Impact of nitrogen amount and timing on the potential of acrylamide formation in winter wheat (Triticum aestivum L.). Field Crops Res.106:44-52.

\section{تأثير المدخلات الأقل فى برنامج مقاومة الحشائش المتكاملة على إنتاج القمح تحت ظروف الأراضي الجديدة

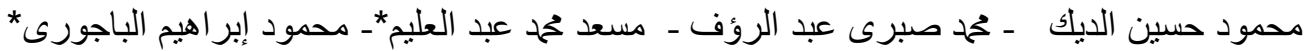

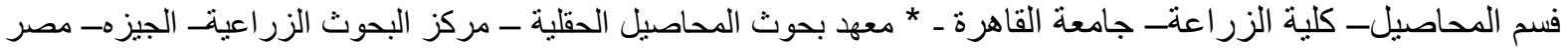

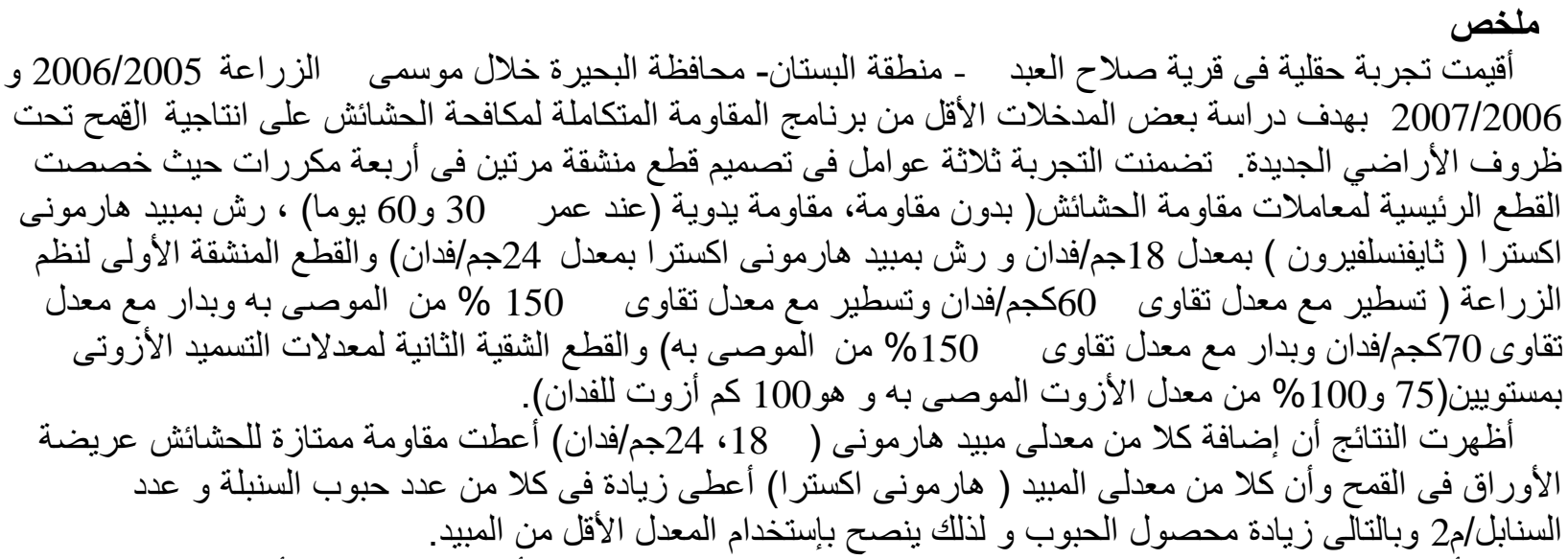

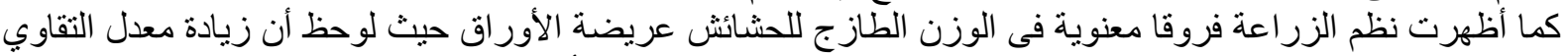

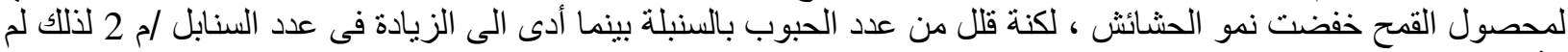

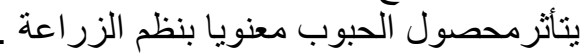

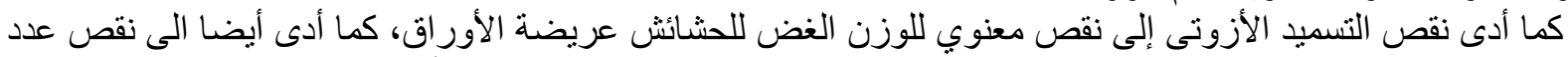

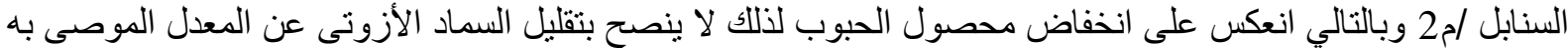

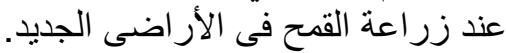
المجلة العلمية لكلية الزراعة - جاعة الارافئ القاهرة - المجلد (61) العدد الثالث (يوليو 2010):237-250. 